Full-length article

\title{
Tetrahydrocurcumin inhibits HT1080 cell migration and invasion via downregulation of MMPs and $\mathrm{UPA}^{1}$
}

\author{
Supachai YODKEEREE ${ }^{2}$, Spiridione GARBISA ${ }^{3}$, Pornngarm LIMTRAKUL ${ }^{2,4}$ \\ ${ }^{2}$ Department of Biochemistry, Chiang Mai University, Chiang Mai, Thailand; ${ }^{3}$ Department of Experimental Biomedical Science, University of \\ Padova, Padova, Italy
}

\section{Key words}

tetrahydrocurcumin; invasion; matrix metalloproteinases; urokinase plasminogen activator

${ }^{1}$ This research was supported by grants from the National Research Council of Thailand and the Royal Golden Jubilee PhD Program of Thailand.

${ }^{4}$ Correspondence to Assoc Prof Pornngarm LIMTRAKUL.

Phn 66-53-94-5323.

Fax 66-53-89-4031.

E-mail plimtrak@mail.med.cmu.ac.th

Received 2007-11-09

Accepted 2008-02-26

doi: 10.1111/j.1745-7254.2008.00792.x

\begin{abstract}
Aim: Tetrahydrocurcumin (THC) is an active metabolite of curcumin. It has been reported to have similar pharmacological activity to curcumin. The proteases that participate in extracellular matrix (ECM) degradation are involved in cancer cell metastasis. The present study investigates the effect of an ultimate metabolite of curcumin, THC, on the invasion and motility of highly-metastatic HT1080 human fibrosarcoma cells. Methods: The effect of THC on HT1080 cell invasion and migration was determined using Boyden chamber assay. Cell-adhesion assay was used for examining the binding of cells to ECM molecules. Zymography assay was used to analyze the effect of THC on matrix metalloproteinase (MMP)-2, MMP-9, and urokinase plasminogen activator (uPA) secretion from HT1080 cells. Tissue inhibitor of metalloproteinase (TIMP)-2 and membrane-type 1 matrix metalloproteinase (MT1-MMP) proteins levels were analyzed by Western blotting. Results: Treatment with THC reduced HT1080 cell invasion and migration in a dose-dependent manner. THC also decreased the cell adhesion to Matrigel and laminin-coated plates. Analysis by zymography demonstrated that treatment with THC reduced the levels of MMP-2, MMP-9, and uPA. THC also inhibited the levels of MT1-MMP and TIMP-2 proteins detected by Western blot analysis. Conclusion: Our findings revealed that THC reduced HT1080 cell invasion and migration. The inhibition of cancer cell invasion is associated with the downregulation of ECM degradation enzymes and the inhibition of cell adhesion to ECM proteins.
\end{abstract}

\section{Introduction}

Cancer metastasis consists of a complex cascade of events. The invasion of cancer cells through the basement membrane occurs via the initial adhesion of cancer cells to the extracellular matrix (ECM) components followed by degradation of the ECM by proteolytic enzymes ${ }^{[1]}$. The key proteases that are involved in the degradation of the ECM are the serine proteases (plasmins), the urokinase plasminogen activator (uPA), cysteine proteases, such as cathepsin $\mathrm{B}$ and L, and matrix metalloproteinases (MMP) ${ }^{[2]}$. Among these enzymes, MMP play a key role in cancer cell invasion and metastasis, which can degrade most components of the $\mathrm{ECM}^{[3]}$. Most MMP are produced in zymogen form (pro-
MMP), requiring activation for catalytic activity. All activated MMP are specifically inhibited by the endogenous inhibitor, tissue inhibitor of metalloproteinase (TIMP) ${ }^{[4]}$. Membrane-type 1 matrix metalloproteinase (MT1-MMP) has been shown to be a key enzyme in tumor metastasis. The role of MT1-MMP in pericellular proteolysis can play a direct role in ECM turnover ${ }^{[5]}$. Moreover, it was identified as the first physiological activator of pro-MMP- $2^{[6]}$. Therefore, the inhibition of ECM degradation enzymes and cell adhesion to ECM molecules could be considered as a preventive approach for cancer metastasis.

Tetrahydrocurcumin (THC) is an active metabolite of curcumin in vivo. After absorption, curcumin undergoes 
metabolism to its sulfate, glucuronide, and sulfated-glucuronide conjugate ${ }^{[7]}$. In the liver, curcumin is reduced by endogenous reductase systems to hexahydrocurcumin, tetrahydrocurcumin, and hexahydrocurcuminol ${ }^{[8]}$, and THC has been demonstrated to be the major curcumin metabolite in vivo ${ }^{[9]}$. THC has been widely studied due to its potential antioxidant, anti-inflammatory, and anticarcinogenic activities, as well as for its ability to modulate multidrug-resistant proteins ${ }^{[10-13]}$. Unlike curcumin, THC is stable in phosphate buffer and in saline at various $\mathrm{pH}$ values; furthermore, it is easily absorbed through the gastrointestinal tract. THC might also play a crucial role in curcumin-induced biological effects.

In recent years, it has also been reported that curcumin induces a reduction in cancer cell invasion in vitro and in vivo by downregulating the level of the ECM degradation enzymes, MMP-2, MMP-9, MMP-3, and MT1-MMP ${ }^{[14-17]}$. However, the effect of the curcumin metabolite, THC, on various aspects of the anti-invasion phenomenon has not been investigated. Thus we explore in the present study the effect of THC on the regulation of the ECM degradation enzymes as well as the invasion of HT1080 cells.

\section{Materials and methods}

Materials Dulbecco's modified Eagle's medium(DMEM) with or without phenol red, penicillin-streptomycin, and trypsin-EDTA were purchased from GIBCO-BRL (Grand Island, NY, USA). Fetal bovine serum (FBS) was purchased from Hyclone (Logan, UT, USA). Collagen type IV, laminin, plasminogen, and casein were purchased from SigmaAldrich (St Louis, MO, USA). Fibronectin and the antibody against MT1-MMP were purchased from Chemicon (Chemicon International, Euromedex, France) and the antibody against TIMP-2 was from Santa Cruz Biotechnology (Santa Cruz, CA, USA). Matrigel was purchased from Becton Dickinson (Bedford, MA, USA).

Cell lines HT1080 human fibrosarcoma and NIH3T3 fibroblasts cells were grown in DMEM supplemented with $100 \mathrm{U} / \mathrm{mL}$ penicillin, $100 \mu \mathrm{g} / \mathrm{mL}$ streptomycin, and $10 \%$ heatinactivated FBS. Cultures were maintained at $37{ }^{\circ} \mathrm{C}$ in a $5 \%$ $\mathrm{CO}_{2} / 95 \%$ air atmosphere.

Preparation of THC THC was prepared as described previously ${ }^{[13]}$. Briefly, curcumin was converted to THC by hydrogenation with $10 \% \mathrm{PtO}_{2}$. After hydrogenation, the crude THC was purified by preparative thin layer chromatography (TLC) $\left(5 \% \mathrm{MeOH}_{\text {in }} \mathrm{CHCl}_{3}, \mathrm{R}_{\mathrm{f}}=0.86\right)$. The identity and purity of THC were confirmed by using mass spectrometer (MS), infrared (IR) spectroscopy, and nuclear magnet resonance (NMR) data.

MTT assay for cell viability Cell viability was measured by the conventional 3-(4,5-dimethylthiazol-2-yl)-2,5diphenyltetrazolium bromide (MTT) reduction assay as described previously ${ }^{[18]}$. Briefly, the HT1080 cells were inoculated at a density of $3 \times 10^{3}$ cells/well in 96-well plates for $24 \mathrm{~h}$ in $200 \mu \mathrm{L}$ DMEM with $10 \%$ FBS; subsequently, the culture supernatant was removed, and DMEM containing various concentrations of THC was added and incubated for $24 \mathrm{~h}$. MTT dye $(15 \mu \mathrm{L}, 5 \mathrm{mg} / \mathrm{mL})$ was added and the plate was incubated for an additional $4 \mathrm{~h}$. The MTT-formazan was dissolved with DMSO, and absorbance was measured using a microplate reader at $570 \mathrm{~nm}$ with a reference wavelength of $630 \mathrm{~nm}$.

Cell invasion and motility assay The invasive and migration behaviors of the HT1080 cells were tested using a modified Boyden chamber assay ${ }^{[19]}$. Polyvinylpyrrolidonefree polycarbonate filters (Millipore, Co. Cork, Ireland) $(8 \mu \mathrm{m}$ pore size) were coated with gelatin $(0.01 \% \mathrm{w} / \mathrm{v})$ for the chemotaxis (cell migration) assay or with Matrigel (15 $\mu \mathrm{g} /$ filter) for the invasion assay. The medium in the lower chamber contained serum-free culture-conditioned medium of NIH3T3 fibroblast cells, which acted as chemoattractants. The HT1080 cells $\left(1 \times 10^{5}\right.$ cells/chamber $)$ were plated onto the upper chamber with or without various concentrations of THC and incubated for $5 \mathrm{~h}$ at $37^{\circ} \mathrm{C}$ in $5 \% \mathrm{CO}_{2}$. After incubation, the noninvading cells were removed from the upper surface of the membrane. The invading cells on the lower surface of the membrane were fixed with methanol for $1 \mathrm{~min}$ and stained with $1 \% \mathrm{w} / v$ of toluidine blue for $5 \mathrm{~min}$. The cells that actively migrated to the under surface of the filter were dissolved with $20 \%$ acetic acid and indirectly quantified by measuring the absorbance at $570 \mathrm{~nm}$. Control experiments were performed in the absence of the chemoattractant. The results of 3 independent experiments were averaged after background subtraction.

Cell-adhesion assay The cell-adhesion assay was performed using a slight modification of a previously-described method $^{[20]}$. In our assay, the 96 -well plates were coated with $100 \mu \mathrm{L} /$ well Matrigel $(25 \mu \mathrm{g} / \mathrm{mL}), 100 \mathrm{~mL} /$ well fibronectin $(10$ $\mu \mathrm{g} / \mathrm{mL}), 100 \mu \mathrm{L} /$ well collagen type IV, or laminin $(20 \mu \mathrm{g} / \mathrm{mL})$, followed by incubation for $16 \mathrm{~h}$ at $4{ }^{\circ} \mathrm{C}$. Non-specific binding sites were blocked with $0.1 \%$ bovine serum albumin for $1 \mathrm{~h}$ at $4{ }^{\circ} \mathrm{C}$ followed by washing 3 times with phosphate-buffered saline (PBS). In the meantime, the HT1080 cells were trypsinized and resuspended in serum-free DMEM solution containing various concentrations of THC; $3 \times 10^{4}$ cells/well were added to each coated well. The cells were incubated at $37^{\circ} \mathrm{C}$ for $1 \mathrm{~h}$, and the non-adherent cells were removed by shaking the plate at $1000 \mathrm{r} / \mathrm{min}$ for $30 \mathrm{~s}$ and washed with DMEM 3 times. The cells were fixed with $4 \%$ paraformalde- 
hyde for $15 \mathrm{~min}$ and stained with $0.5 \% \mathrm{w} / \mathrm{v}$ crystal violet in $20 \%$ methanol for $10 \mathrm{~min}$. Unbound dye was removed in tap water, and the plate was dried in air. Bound dye was extracted with $20 \%$ acetic acid. The absorbance of the samples was measured at $570 \mathrm{~nm}$ using a microplate reader.

Zymography The secretions of MMP-2 and MMP-9 in the culture-condition medium were assayed by gelatin zymography ${ }^{[21]}$. The HT1080 cells $\left(1 \times 10^{5}\right.$ cells/well $)$ were seeded into 6-well plates and maintained for $24 \mathrm{~h}$ in DMEM with $10 \%$ FBS. Subconfluent cell cultures were incubated for $24 \mathrm{~h}$ in various concentrations of THC in serum-free DMEM, and the culture supernatants were collected from equal numbers of cells. Without heating and under nonreducing conditions, the samples were subjected to electrophoresis in $0.1 \% \mathrm{w} / \mathrm{v}$ gelatin-containing $10 \%$ PAGE in the presence of SDS. After electrophoresis, the gel was washed 2 times for $30 \mathrm{~min}$ in $2.5 \%$ Triton X 100 and incubated for $18 \mathrm{~h}$ at $37^{\circ} \mathrm{C}$ in Tris buffer $(50 \mathrm{mmol} / \mathrm{L}$ Tris- $\mathrm{HCl}, 200 \mathrm{mmol} / \mathrm{L} \mathrm{NaCl}$, and $10 \mathrm{mmol} / \mathrm{L} \mathrm{CaCl}_{2}, \mathrm{pH}$ 7.4). The gels were stained with Coomassie Brilliant Blue R $(0.1 \% \mathrm{w} / \mathrm{v})$ and destained in a solution of $30 \%$ methanol and $10 \%$ acetic acid. Gelatinolytic activity appeared as a clear band on a blue background. Digestion bands were quantified by Bio-1D software (Viber Lourmat, Marne-la-Vallée, France).

The uPA secretion in the culture-conditioned medium was examined by casein-plasminogen zymography ${ }^{[22]}$. The culture supernatant was separated by electrophoresis in $10 \%$ polyacrylamide gel (PAGE) in the presence of SDS, which was copolymerized with $1 \mathrm{mg} / \mathrm{mL} \beta$-casein and $10 \mathrm{mg} / \mathrm{mL}$ human plasminogen under non-reducing conditions. After electrophoresis, the gel was washed 2 times for $30 \mathrm{~min}$ in $2.5 \%$ Triton X 100 and incubated for $18 \mathrm{~h}$ at $37^{\circ} \mathrm{C}$ in Tris buffer $(50$ $\mathrm{mmol} / \mathrm{L} \mathrm{Tris-HCl}, 200 \mathrm{mmol} / \mathrm{L} \mathrm{NaCl}$, and $10 \mathrm{mmol} / \mathrm{L} \mathrm{CaCl}_{2}$, $\mathrm{pH}$ 7.4). The gels were stained and destained as described earlier.

Preparation of conditioned media and whole cell lysates The HT1080 cells ( $1 \times 10^{6}$ cells/flask) were seeded into $75 \mathrm{~mm}^{3}$ $\mathrm{T}$ flasks and maintained for $24 \mathrm{~h}$ in DMEM with $10 \% \mathrm{FBS}$. Subconfluent cell cultures were incubated for $24 \mathrm{~h}$ in various concentrations of THC in serum-free DMEM without phenol red. After treatment, the culture supernatant was collected and concentrated with Amicon-Ultra 4 (Millipore, Ireland) for the TIMP-2 analysis, and the cells were washed twice with ice-cold PBS and scraped with a cell scraper into ice-cold PBS. The cells were centrifuged at $500 \times \mathrm{g}$ for $10 \mathrm{~min}$, the supernatant was removed, and the cell pellets were lysed with a lysis buffer containing protease inhibitor $(50 \mathrm{mmol} / \mathrm{L}$ Tris $\mathrm{HCl}, 150 \mathrm{mmol} / \mathrm{LNaCl}, 10 \mathrm{mmol} / \mathrm{LEDTA}, 1 \%$ Triton X 100, $1 \mathrm{mmol} / \mathrm{L}$ phenylmethysulfonyl fluoride (PMSF), $10 \mu \mathrm{g} / \mathrm{mL}$ leupeptin, and $10 \mu \mathrm{g} / \mathrm{mL}$ apotinin) for $30 \mathrm{~min}$ on ice. The insoluble matter was removed by centrifugation at $12000 \times g$ for $15 \mathrm{~min}$ at $4{ }^{\circ} \mathrm{C}$, and the supernatant fraction was collected for MT1-MMP analysis.

Western blot analysis of TIMP-2 and MT1-MMP The expressions of the MT1-MMP and TIMP-2 proteins were determined by immunoblotting with specific antibodies. Briefly, equal amounts of lysates or concentrated-conditioned media proteins from control and treated cells were resuspended in sample buffer and separated by SDS-PAGE using $10 \%$ acrylamide gels. After electrophoresis, the proteins were electroblotted to a Hybond-C extra nitrocellulose membrane (Amersham, Little Chalfont, UK). The membrane was blocked at room temperature (RT) with 5\% non-fat dry milk in PBS containing 0.3\% Tween-20 (PBS-T). The membrane was washed twice with PBS-T and incubated $2 \mathrm{~h}$ at RT with the primary antibody, rabbit polyclonal anti-MT1-MMP (1:2000; Chemicon, France) or mouse monoclonal anti-TIMP-2 (1:200; Santa Cruz Biotechnology, USA). After washing 5 times with PBS-T, the membrane was incubated with the second antibodies at RT for $1 \mathrm{~h}$ in PBS-T containing 5\% non-fat dry milk. After incubation, the membrane was washed with PBS-T 5 times. The second antibodies were horseradish peroxidase-conjugated antirabbit immunoglobulin $\mathrm{G}$ (IgG; 1 : 10,000; Amersham, UK) or antimouse IgG(1:10,000; Chemicon, France). After incubation, the immunoreactive material was visualized by enhanced chemiluminescence and exposed to X-ray film (Kodak, Windsor, Colorado, USA) for periods of 5-30min.

Statistical analysis Statistical analyses were performed using one-way ANOVA. $P<0.01$ was considered statistically significant. All statistical analyses were performed using SPSS 10.0 software (SPSS, Chicago, IL, USA).

\section{Results}

Effect of THC on the cytotoxicity of HT1080 cells The effect of various concentrations of THC $(0-100 \mu \mathrm{mol} / \mathrm{L})$ on the viability of HT1080 cells was assayed by MTT. Treatment with high concentrations of THC (up to100 $\mu \mathrm{mol} / \mathrm{L}$ ), for $24 \mathrm{~h}$ did not affect the cytotoxicity to HT1080 cells (Figure 1). This concentration range was used in all subsequent experiments.

THC inhibited the invasion and migration of HT1080 cells The effect of THC on the invasiveness and motility of HT1080 cells was determined by Boyden chamber assay. THC reduced the invasion of HT1080 through Matrigel (reconstitutive basement membrane) in a dose-dependent manner, with an inhibitory concentration at $50 \%$ of control $\left(\mathrm{IC}_{50}\right)$ value of $>100 \mu \mathrm{mol} / \mathrm{L}$ (Figure $2 \mathrm{~A}$ ). THC also inhibited 


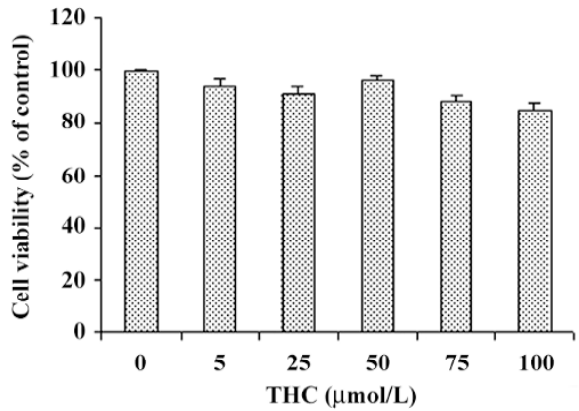

Figure 1. Effect of THC on the cytotoxicity of HT1080 cells. Cells were treated with the indicated concentrations of THC for $24 \mathrm{~h}$ before being subjected to MTT assay. Data represent the mean $\pm \mathrm{SD}$ of 3 independent experiments.
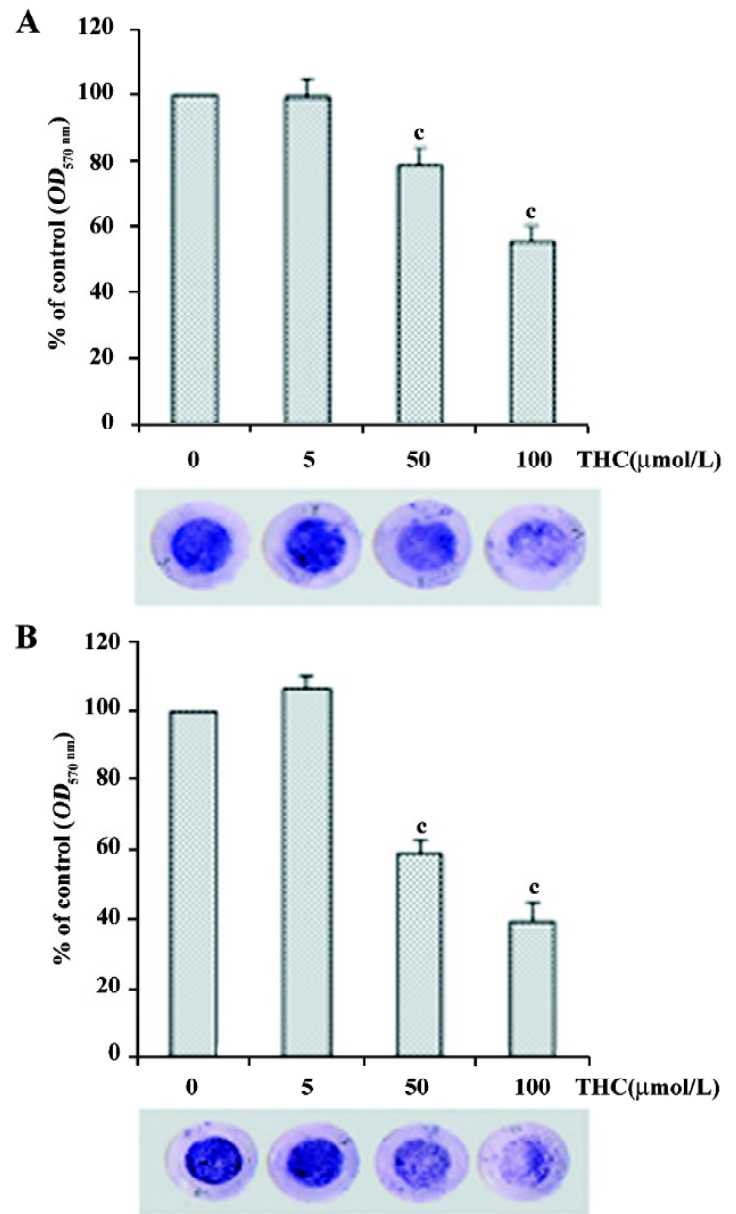

Figure 2. Effect of THC on HT1080 cell invasion (A) and migration (B). HT1080 cells were seeded onto a filter coated with Matrigel (A) or gelatin (B) containing THC at the indicated concentrations $(0-100 \mu \mathrm{mol} / \mathrm{L})$ and then incubated for $5 \mathrm{~h}$ at $37^{\circ} \mathrm{C}$. Cells that actively migrated to the lower surface of the filter were quantified. Invasion and migration are expressed as a percentage of the untreated control. Data represent the mean $\pm \mathrm{SD}$ of 3 independent experiments. ${ }^{\mathrm{c}} P<0.01$. the migration of the cells through the gelatin-coated filters in a dose-dependent manner, with an $\mathrm{IC}_{50}$ value of $75 \mu \mathrm{mol} / \mathrm{L}$ (Figure 2B).

Effect of THC on HT1080 cell adhesion to Matrigel, fibronectin, laminin, and collagen type IV Assuming that the adhesion of cancer cells to ECM molecules is the first step of tumor cell invasion, we further determined the effect of THC on the adhesion of HT1080 cells to Matrigel, fibronectin, laminin, and collagen type IV substrates. HT1080 cells were treated with THC at concentrations ranging from 0 to $100 \mu \mathrm{mol} / \mathrm{L}$. THC inhibited the adhesion of the cells to Matrigel and laminin in a dose-dependent manner, with an $\mathrm{IC}_{50}$ value of $>100$ and $90 \mu \mathrm{mol} / \mathrm{L}$, respectively (Figure 3 ). In contrast, THC did not affect the cell adhesion to fibronectin and collagen type IV-coated plates.

THC reduced the secretion of MMP-2, MMP-9, and uPA from HT1080 cells To investigate whether THC can inhibit the secretion of MMP-2, MMP-9, and uPA from HT1080 cells, the cells were treated with various concentrations of THC $(0-100 \mu \mathrm{mol} / \mathrm{L})$ in serum-free medium for $24 \mathrm{~h}$. The levels of MMP-2, MMP-9, and uPA were analyzed by zymography. The levels of total MMP-2 (pro and active form) and ProMMP-9 were reduced by THC in a dose-dependent manner, with an $\mathrm{IC}_{50}$ value of $85 \mu \mathrm{mol} / \mathrm{L}$ and $>100 \mu \mathrm{mol} / \mathrm{L}$, respectively (Figure 4A). The uPA (pro and active form) level was also inhibited by THC in a dose-dependent manner, with an $\mathrm{IC}_{50}$ value of $80 \mu \mathrm{mol} / \mathrm{L}$ (Figure 4B).

Effect of THC on MT1-MMP and TIMP-2 expressions in HT1080 cells To examine the influence of THC on the modulation of pro-MMP-2 activation, we assessed the TIMP-2 and MT1-MMP protein expressions in THC-treated cells. After the cells were treated with various concentrations of THC, the culture supernatant was used for determination of the TIMP-2 level, and the cell lysates were used for determination of the MT1-MMP protein level. As shown in Figure $5 \mathrm{~A}$, THC decreased the TIMP-2 protein level in a dose-dependent manner, with an $\mathrm{IC}_{50}$ value in the range of $75 \mu \mathrm{mol} / \mathrm{L}$. Total MT1-MMP protein levels were also significantly reduced by treatment with THC in a dose-dependent manner, with an $\mathrm{IC}_{50}$ value in the range of $100 \mu \mathrm{mol} / \mathrm{L}$ (Figure 5B), demonstrating that THC reduced the protein levels of both TIMP-2 and MT1-MMP.

\section{Discussion}

In recent years, it has been reported that curcumin exhibits antimetastatic properties in vivo and in vitro ${ }^{[14,15]}$. The pharmacokinetic features of curcumin in several species have indicated poor systemic bioavailability, which may be related to its inadequate absorption and avid metabolism ${ }^{[8,9,23,24]}$. 


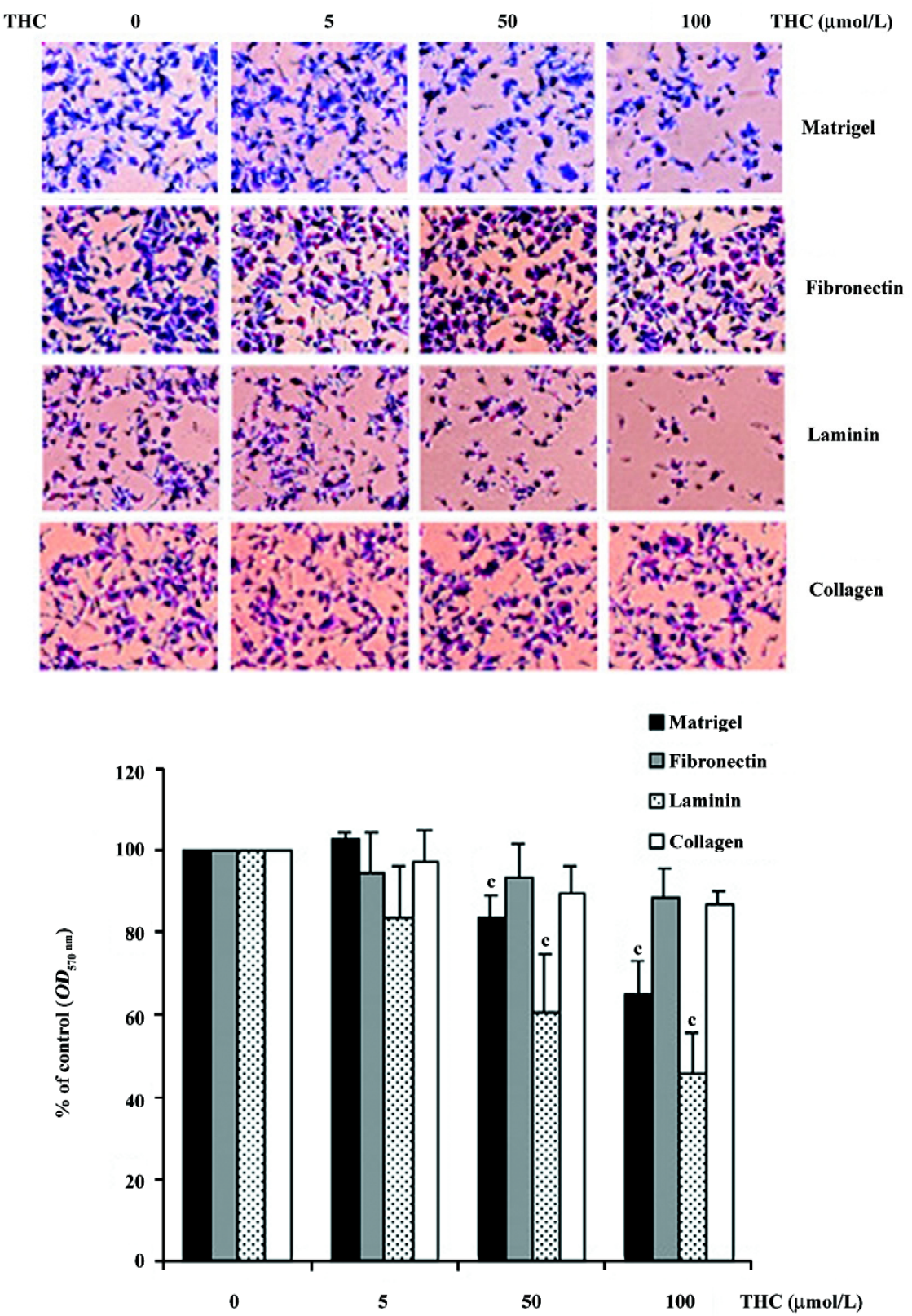

Figure 3. Effect of THC on the adhesion of HT1080 cells to the ECM molecules. Cancer cells were added to wells precoated with Matrigel, fibronectin, laminin, and collagen type IV in the presence or absence of the indicated concentration of THC. After $1 \mathrm{~h}$ of incubation, nonadherent cells were removed, and adherent cells were stained using crystal violet staining. After extensive washing, the stained cells were lysed with $10 \%$ acetic acid, and the absorbance was measured at $570 \mathrm{~nm}$. Cancer cell adhesion is expressed as a percentage of the untreated control. Data represent the mean $\pm \mathrm{SD}$ of 3 independent experiments. ${ }^{\mathrm{c}} P<0.01$.

After oral administration, curcumin is rapidly metabolized by enzymes in the intestine and liver. THC has been demonstrated as one of the major metabolites of curcumin in vivo ${ }^{[25]}$.

It is well known that tumor cell metastasis is a complex cascade of events. The process involves multiple steps, such as cell adhesion, ECM component degradation, and tumor cell migration. Hence, interruption of 1 or more of these steps is one approach for antimetastatic therapy. To date, there is no evidence to show that THC exerts an effect on cancer cell metastasis. The present study is the first to demonstrate that THC at non-cytotoxic doses significantly inhibits HT1080 cell invasion through the basement membrane.

The initial invasive action of metastatic cells involves the interaction of tumor cells with the ECM molecules through the process of cell matrix adhesion ${ }^{[26-28]}$. The result from our cell-adhesion assay shows that THC significantly reduced 


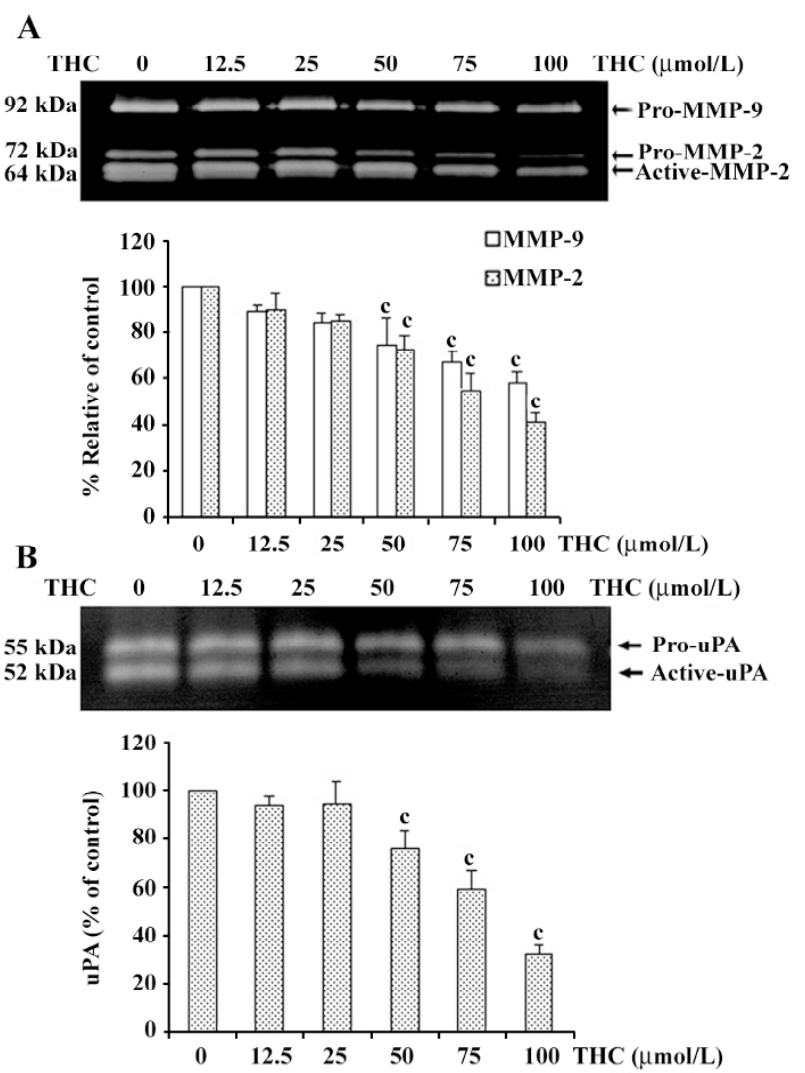

Figure 4. THC inhibits the secretion level of MMP-2, MMP-9, and uPA from HT1080 cells. After the HT 1080 cells were treated with THC at the indicated concentrations $(0-100 \mu \mathrm{mol} / \mathrm{L})$ for $24 \mathrm{~h}$ in serum-free medium, an equal amount of proteins was loaded ( $5 \mu \mathrm{g} / \mathrm{lean})$. Gelatin zymography was performed for MMP-2 and MMP-9 activities in culture-conditioned medium (A). UPA activity was analyzed by caseinplasminogen zymography (B). Levels of MMP-2 (pro and active form), MMP-9 (pro form), and uPA (pro and active form) activities were quantified by densitometric analysis with that of the untreated group being $100 \%$ as shown just below the gel. Data represent the mean \pm SD of 3 independent experiments. ${ }^{c} P<0.01$.

HT1080 cell adhesion to Matrigel (reconstituted basement membrane). This result led us to investigate further which ECM molecules in Matrigel were blocked by THC. Our results demonstrate that THC reduced HT1080 cell adhesion to laminin, but not to collagen type IV and fibronectin. The above data indicate that THC blocked the binding between cancer cells and laminin, which led to the observed inhibition of cancer cell adhesion to Matrigel.

The process of tumor cell metastasis requires the degradation of ECM molecules in the basement membrane, which is the largest barrier between cancer cells and the bloodstream; it must disintegrate before cancer cells can enter the circulatory system. The key proteases that are involved in ECM degradation are MMP and serine proteases, such as uPA.

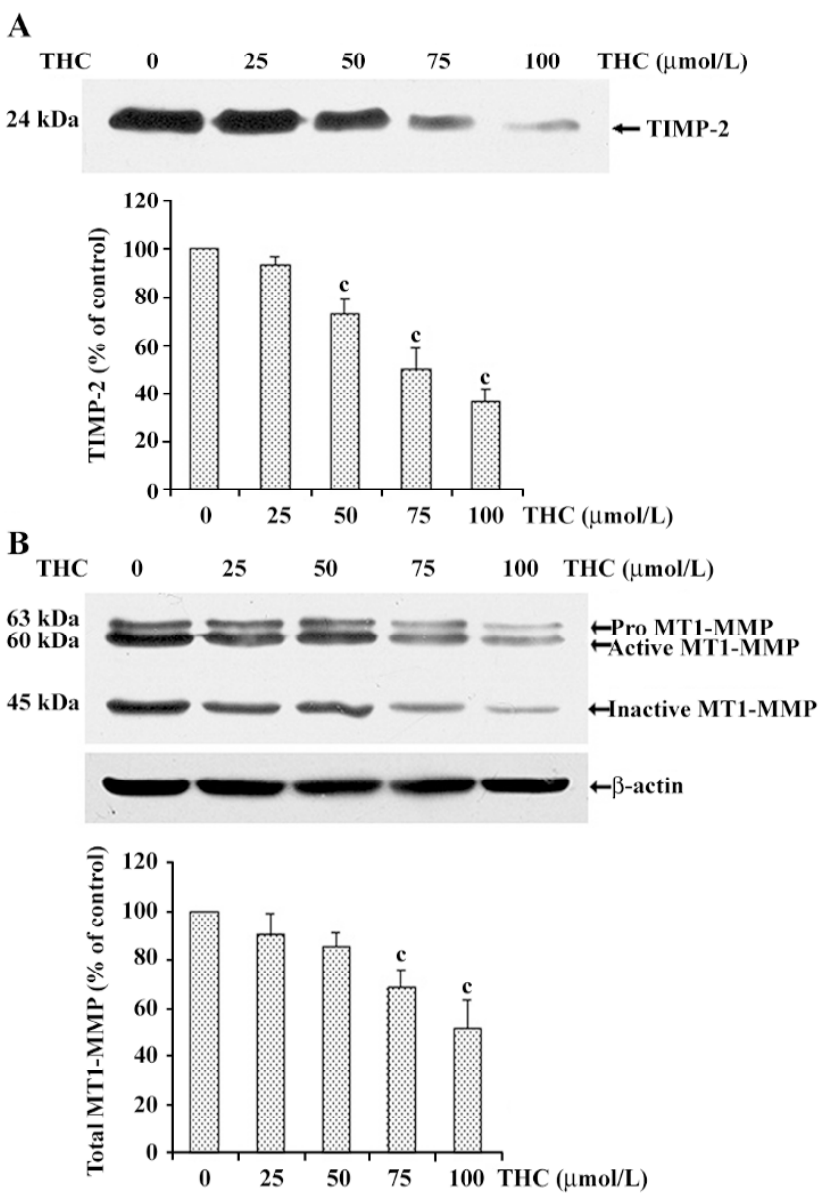

Figure 5. Analysis of the THC effect on the TIMP-2 and MT1MMP protein expressions in HT1080 cells was performed using Western blot analysis. HT1080 cells were treated with THC at the indicated concentrations $(0-100 \mu \mathrm{mol} / \mathrm{L})$ for $24 \mathrm{~h}$, the conditioned medium was collected and concentrated for TIMP-2 determination (A), and the cell lysate was used for MT1-MMP determination (B). Equal amounts of proteins were loaded ( $40 \mu \mathrm{g} / \mathrm{lane}$ for TIMP-2 and $50 \mu \mathrm{g} / \mathrm{lane}$ for MT1-MMP). Band intensity of TIMP-2 and total MT1-MMP were quantified by densitometry, where the untreated group represented $100 \%$. Data represent the mean \pm SD of 3 independent experiments. ${ }^{\mathrm{c}} P<0.01$.

Although several enzymes are involved in this process, it appears that MMP-2 and MMP-9 play important roles in cell invasion because both enzymes degrade type IV collagen, a major component of the basement membrane ${ }^{[29]}$. In the present study, we investigated the effect of THC on MMP-2, MMP-9, and uPA secretion from HT1080 cells using zymography assay. The results revealed that THC significantly reduces MMP-2, MMP-9, and uPA secretion from the cells in a dose-dependent manner. These data collectively support the inhibitory effect of THC on cancer cell invasion.

In particular, MMP-2 is constitutively expressed and secreted as a latent zymogen, pro-MMP-2, and its main activa- 
tion takes place on the cell surface; this process is mediated by MT1-MMP and TIMP-2 $2^{[30-32]}$. After activation, MT1MMP proteolytic processing leads to its $45 \mathrm{kDa}$ inactive form $^{[33,34]}$. The appearance of this inactive MT1-MMP form has been strongly correlated with MMP-2 activation ${ }^{[35]}$. In the present study, we found that THC significantly reduced total MT1-MMP (pro, active, and inactive form). This result suggests that THC decreases pro-MMP2 activation through a reduced MT1-MMP level. Interestingly, THC decreases the TIMP-2 level, even though TIMP-2 is considered to be inhibitor of MMP-2; however, the relationship between MMP-2 and TIMP-2 with regard to anticancer metastasis remains a topic of controversy. For example, several studies have reported that decreased levels of MMP-2 together with increased levels of TIMP-2 might lead to reduced cancer cell invasion $^{[36]}$. However, other reports argue that anticancer cell invasion correlates with decreased levels of both MMP-2 and TIMP-2 $2^{[37,38]}$

In conclusion, we report that THC, a major metabolite of curcumin, inhibits cancer cell invasion and motility. The inhibition was effected by decreasing the secretion of ECM degradation enzymes from invasive cells and by blocking the cell adhesion to Matrigel. However, its exact mechanism of action remains elusive. This study provides additional evidence that THC can inhibit metastasis activity in cancer cells.

\section{Author contribution}

Pornngarm LIMTRAKUL, Supachai YODKEEREE designed research;Supachai YODKEEREE performed research; Spiridione GARBISA contributed new reagents or analytic tools; Supachai YODKEEREE, Pornngarm LIMTRAKUL analyzed data; Pornngarm LIMTRAKUL wrote the paper.

\section{References}

1 Cavallaro U, Christofori G. Cell adhesion in tumor invasion and metastasis: loss of the glue is not enough. Biochim Biophys Acta 2001; 1552: 39-45.

2 Liotta LA, Trygguason K, Garbisa S, Hart I, Foltz CM, Shafie S. Metastasis potential correlate with enzymatic degradation of basement membrane collagen. Nature 1980; 284: 67-8.

3 Cox G, O’Byrne KJ. Matrix metalloproteinases and cancer. Anticancer Res 2001; 21: 4207-19.

4 Gomez DE, Alonso DF, Yoshiji H, Thorgeirsson UP. Tissue inhibitor of metalloproteinase: structure, regulation and biological functions. Eur J Cell Biol 1997; 74: 111-22.

5 Sato H, Okada Y, Seiki M. Membrane-type matrix metalloproteinases (MT1-MMPs) in cell invasion. Thromb Haemost 1997; 78: 497-500.

6 Strongin AY, Collier I, Bannikov G, Marmer BL, Gran GA, Goldberg GI. Mechanism of cell surface activation of 72-kDa type IV collagenase isolation of the activated form of the membrane metalloprotease. J Biol Chem 1995; 270: 5331-8.

7 Asai A, Miyazawa T. Occurrence of orally administered curcuminoids as glucuronide and glucuronide/sulfate conjugates in rat plasma. Life Sci 2000; 67: 2785-93.

8 Ireson CR, Orr S, Jones DJL, Verschoyle R, Lim CK, Luo JL, et al. Characterization of metabolites of the chemopreventive agent curcumin in human and rat hepatocytes and in rat plasma and evaluation of their ability to inhibit phorbol ester-induced prostaglandin $\mathrm{E}_{2}$ production. Cancer Res 2001; 61: 1058-64.

9 Pan MH, Huang TM, Lin JK. Biotransformation of curcumin through reduction and glucuronidation in mice. Drug Metab Dispos 1999; 27: 486-94.

10 Osawa T, Kato Y. Protective role of antioxidative food factors in oxidative stress caused by hyperglycemia. Ann NY Acad Sci 2005; 1043: 440-51.

11 Sandur SK, Pandev MK, Sung B, Ahn KS, Murakami A, Sethi G, et al. Curcumin, demethoxycurcumin, bisdemethoxycurcumin, tetrahydrocurcumin and tumerones differentially regulate antiinflammatory and anti-proliferative response through a ROSindependent mechanism. Carcinogenesis 2007; 28: 1765-73.

12 Pari L, Amali DR. Protective role of tetrahydrocurcumin (THC) an active principle of turmeric on chloroquine induced hepatotoxicity in rat. J Pharm Pharm Sci 2005; 8: 115-23.

13 Limtrakul P, Chearwae W, Shukla S, Phisalphong C, Ambudkar $\mathrm{SV}$. Modulation of function of three ABC drug transporters, $\mathrm{P}$ glycoprotein (ABCB1), mitoxantrone resistance protein (ABCG2) and multidrug resistance protein $1(\mathrm{ABCC} 1)$ by tetrahydrocurcumin, a major metabolite of curcumin. Mol Cell Biochem 2007; 296: 85-95.

14 Aggarwal S, Ichikawa H, Takada Y, Sandur SK, Shishodia S, Aggarwal BB. Curcumin (diferuloylmethane) down-regulates expression of cell proliferation and antiapoptotic and metastatic gene products through suppression of IKappa Balpha kinase and AKT activation. Mol Pharmacol 2006; 69: 195-206.

15 Bachmeier B, Nerlich AG, Iancu CM, Cili M, Schleicher E, Vene $\mathrm{R}$, et al. The chemopreventive polyphenol curcumin prevents hematogenous breast cancer metastasis in immunodeficient mice. Cell Physiol Biochem 2007; 19: 137-52.

16 Ohashi Y, Tsuchiya Y, Koizumi K, Sakurai H, Saiki I. Prevention of intrahepatic metastasis by curcumin in an orthotopic implantation model. Oncology 2003; 65: 250-8.

17 Chen HW, Yu SL, Chen JJW, Li HN, Lin CV, Yao PL, et al. Antiinvasive gene expression profile of curcumin in lung adenocarcinoma based on a high throughput microarray analysis. Mol Pharmacol 2004; 65: 99-110.

18 Mosman T. Rapid colorimetric assay for cellular growth and survival: application to proliferlation and cytotoxicity assays. J Immunol Methods 1983; 65: 55-63.

19 Dona M, Dell' Aica I, Pezzato E, Sator L, Calabrese F, Barbera $\mathrm{MD}$, et al. Hyperforin inhibits cancer invasion and metastasis. Cancer Res 2004; 64: 6225-32.

20 Harimaya Y, Koizumi K, Andoh T, Nojima H, Kuraishi Y, Saiki T. Potential ability of morphine to inhibit the adhesion, invasion and metastasis of metastatic colon 26-L5 carcinoma cells. Cancer Lett 2002; 187: 121-7.

21 Garbisa S, Sartor L, Biggin S, Salvato R, Benelli R, Albini A. Tumor gelatinase and invasion inhibited by the green tea fla- 
vonol epigallocatechin-3-gallate. Cancer 2001; 91: 822-32.

22 Law B, Hsiao JK, Bugge TH, Weissleder R, Tung CH. Optical zymography for specific detection of urokinase plasminogen activator activity in biological samples. Anal Biochem 2005; 338: $151-8$.

23 Garcea G, Berry DP, Jones DJ, Singh R, Dennison AR, Farmer $\mathrm{PB}$, et al. Consumption of the putative chemopreventive agent curcumin by cancer patients: assessment of curcumin levels in the colorectum and their pharmacodynamic consequences. Cancer Epidermiol Biomarker Prev 2005; 14: 120-5.

24 Garcea G, Jones DJ, Singh R, Dennison AR, Farmer PB, Sharma RA, et al. Detection of curcumin and its metabolites in hepatic tissue and portal blood of patients following oral administration. Br J Cancer 2004; 8: 1011-5.

25 Ireson CR, Jones DJ, Orr S, Coughtric MW, Boocock DJ, Williams ML, et al. Metabolism of cancer chemopreventive agent curcumin in human and rat intestine. Cancer Epidemiol Biomarker Prev 2002; 11: 105-11.

26 Bogenrieder T, Herlyn M. Axis of evil: molecular mechanisms of cancer metastasis. Oncogene 2003; 22: 6524-36.

27 Ramsay AG, Marshall JF, Hart IR. Integrin trafficking and its role in cancer metastasis. Cancer Metastasis Rev 2007; 26: 56778.

28 Luo BH, Carman CV, Springer TA. Structure basis of integrin regulation and signaling. Annu Rev Immunal 2007; 25: 619-47.

29 Stetler-stenvenson WG. Type IV collagease in tumor invasion and metastasis. Cancer Metastasis Rev 1990; 9: 289-303.

30 Visse R, Nagase H. Matrix metalloproteinase and tissue inhibitor of metalloproteinase: structure function and biochemistry. Circ Res 2003; 92: 827-39.

31 Sato H, Takino T, Okada Y, Cao J, Shinaguwa A, Yamanoto E, et al. Matrix metalloproteinase expression on the surface of inva- sion tumor cell. Nature 1994; 370: 61-5.

32 Butler Gs, Butler MJ, Alkinson ST, Will H, Tamara T, Westrum $\mathrm{SS}$, et al. The TIMP-2 membrane type 1 metalloproteinase "receptor" regulation the concentration and efficient activation of progelatinase A. J Biol Chem 1998; 273: 871-80.

33 Hernandez Barrantes S, Toth M, Bernardo M, Yorkova M, Gervasi DC, Raz Y, et al. Binding of active $(57 \mathrm{kDa})$ membrane type 1matrix metalloproteinase (MT1-MMP) to tissue inhibitor of metalloproteinase (TIMP-2) regulates MT1-MMP processing and pro-MMP-2 activation. J Biol Chem 2000; 275: 12080-9.

34 Satanton H, Gavrilovic J, Atkinson SJ, d'Ortho MP, Yamada KM, Zardi L, et al. The activation of Pro-MMP-2(gelatinase A ) by HT1080 fibrosarcoma cells is promoted by culture on a fibronectin substrate and is concomitant with an increase in processing of MT1-MMP(MMP-14) to a $45 \mathrm{kDa}$ form. J Cell Sci 1998; 111: 2789-98.

35 Gingras D, Page M, Annabi B, Beliveau R. Rapid activation of matrix metalloproteinase-2 by glioma cells occurs through a posttranslational MT1-MMP dependent mechanism. Biochim Biophys Acta 2000; 1497: 341-50.

36 Chu SC, Chiou HL, Chen PN, Yang SF, Hsieh YS. Silibinin inhibits the invasion of human lung cancer cells via decreased production of urokinase-plasminogen activator and matrix metalloproteinase-2. Mol Carcinogen 2004; 40: 143-9.

37 Park HJ, Chung HJ, Min HY, Park EJ, Hong JY, Kim WB. Inhibitory effect of DA-125, a new anthracyclin analog antitumor agent, on the invasion of human fibrosacroma cells by downregulating the matrix metalloproteinase. Biochem Pharmacol 2005; 71: 21-31.

38 Chu SC, Yang SF, Liu SJ, Kuo WH, Chang YZ, Hsieh YS. In vitro and in vivo antimetastatic effects of Terminalia catappa L leaves on lung cancer cells. Food Chem Toxicol 2007; 45: 1194-201. 